\title{
Structure-activity Relationships of Xanthocillin Derivatives as Thrombopoietin Receptor Agonist
}

\author{
Takahiro Yamaguchi, Yumi Miyake, Atsushi Miyamura, Norihisa Ishiwata, \\ Kuniaki Tatsuta
}

Received: August 10, 2006 / Accepted: October 24, 2006

(C) Japan Antibiotics Research Association

\begin{abstract}
Xanthocillin derivatives, which show thrombopoietin receptor agonist activity, were synthesized through our developed method. Bioassay data suggest the importance of alkene geometry, the presence of substituents at the benzene ring that support hydrophobic character, and the moderate size of the molecule. One of the two isonitrile group of the natural product appears to be dispensable.
\end{abstract}

Keywords xanthocillin, structure-activity relationships, anti-viral activities, thrombopoietin receptor agonist

Thrombopoietin (TPO) is a cytokine that regulates platelet production by stimulating proliferation and differentiation of hematopoietic stem cells, megakaryocytic progenitor cells and megakaryocytes via activation of its receptor, c$\mathrm{Mpl}$ [1]. Thrombocytopenia, or low platelet count, is one of the serious adverse events that occur as a result of intensive cancer chemotherapy or other treatments [2]. Although recombinant human (rh)TPO has been proven to be effective for such thrombocytopenia, some difficulties, such as development of neutralizing antibodies against TPO, have been reported [3]. Additionally, rhTPO and low molecular weight peptides with affinity for TPO receptor are unstable in the intestines thus limiting oral administration. Therefore, orally active, low molecular weight compounds with agonistic action on TPO receptor are in demand and several small synthetic TPO receptor

K. Tatsuta (Corresponding author), T. Yamaguchi, Y. Miyake: Department of Chemistry, School of Science and Engineering, Waseda University, 3-4-1 Ohkubo, Shinjyuku-ku, Tokyo 1698555, Japan, Email: tatsuta@waseda.jp activators have been reported [4].

Xanthocillin derivatives $\mathbf{1} \sim \mathbf{3}$ were originally isolated from cultures of soil fungus Aspergillus sp. in view of their anti-viral activities [5]. Sakai, R., et al., however, disclosed recently that compounds $\mathbf{1} \sim \mathbf{4}$ (Fig. 1), isolated from culture marine fungus Basipetospora sp., were the first natural products with TPO receptor agonist activity [6]. These compounds promoted the proliferation of a TPO-sensitive human leukemia cell line in a dose-dependent manner, and we have also reported the stereoselective synthesis of xanthocillin X dimethylether (2, XDE, Scheme 1) [7]. Applying our developed method, we have herein prepared several analogs to enable the study of structure-activity relationships.

Maintaining the 2,3-diisocyano-buta-1,3-diene moiety of

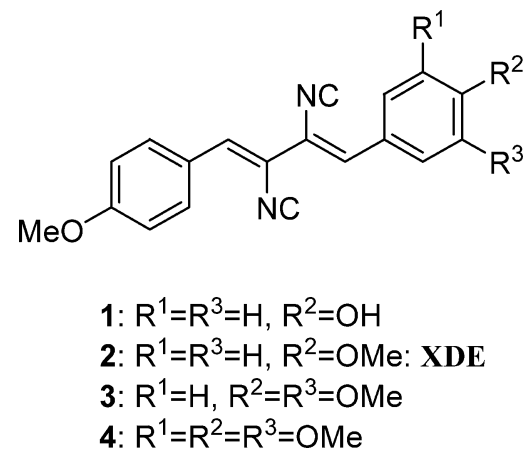

Fig. 1
A. Miyamura, N. Ishiwata: Biological Research Laboratories, Nissan Chemical Industries, Ltd., Shiraoka, Minamisaitama, Saitama 349-0294, Japan 




Scheme 1.

Table 1 Physico-chemical properties of bioassayed compounds

\begin{tabular}{|c|c|c|}
\hline Compds. & $\begin{array}{l}\mathrm{Mp}\left({ }^{\circ} \mathrm{C}\right) \\
\mathrm{FAB}-\mathrm{MS}(\mathrm{m} / \mathrm{z}) \\
\operatorname{IR}(\mathrm{KBr}) v_{\mathrm{N}=\mathrm{C}}\left(\mathrm{cm}^{-1}\right)\end{array}$ & $\begin{array}{l}{ }^{1} \mathrm{H}-\mathrm{NMR}(400 \mathrm{MHz} ; \delta \mathrm{ppm}) \\
{ }^{13} \mathrm{C}-\mathrm{NMR}(100 \mathrm{MHz} ; \delta \mathrm{ppm})\end{array}$ \\
\hline $14 b$ & $\begin{array}{l}145 \sim 147(\mathrm{dec}) \\
256\left(\mathrm{M}^{+}\right) \\
2114\end{array}$ & $\begin{array}{l}{ }^{1} \mathrm{H}-\mathrm{NMR}\left(\mathrm{CDCl}_{3}\right) 7.18(2 \mathrm{H}, \mathrm{s}), 7.46(6 \mathrm{H}, \mathrm{m}), 7.82(4 \mathrm{H}, \mathrm{d}, J=8.4 \mathrm{~Hz}) . \\
{ }^{13} \mathrm{C}-\mathrm{NMR}\left(\mathrm{CDCl}_{3}\right) 118.1,128.9,129.0,130.0,130.5,131.9,174.0 .\end{array}$ \\
\hline $15 a$ & $\begin{array}{l}135(\mathrm{dec}) \\
289(\mathrm{M}+\mathrm{H})^{+} \\
2134\end{array}$ & $\begin{array}{l}{ }^{1} \mathrm{H}-\mathrm{NMR}\left(\text { Acetone- } d_{6}\right) 6.94(4 \mathrm{H}, \mathrm{d}, J=8.4 \mathrm{~Hz}), 7.04(2 \mathrm{H}, \mathrm{s}), 7.78(4 \mathrm{H}, \mathrm{d}, J=8.4 \mathrm{~Hz}) \text {. } \\
{ }^{13} \mathrm{C}-\mathrm{NMR}\left(\text { Acetone- } d_{6}\right) 116.9,117.2,125.2,128.7,133.2,160.8,175.3 .\end{array}$ \\
\hline 16 & $\begin{array}{l}134(\mathrm{dec}) \\
291\left(\mathrm{M}^{+}\right) \\
2015\end{array}$ & $\begin{array}{l}{ }^{1} \mathrm{H}-\mathrm{NMR}\left(\mathrm{CDCl}_{3}\right) 3.84(3 \mathrm{H}, \mathrm{s}), 3.86(3 \mathrm{H}, \mathrm{s}), 6.43(1 \mathrm{H}, \mathrm{s}), 6.58(1 \mathrm{H}, \mathrm{d}, J=15.2 \mathrm{~Hz}), 6.90(2 \mathrm{H}, \mathrm{d}, \\
J=8.8 \mathrm{~Hz}), 6.91(1 \mathrm{H}, \mathrm{d}, J=15.2 \mathrm{~Hz}), 6.95(2 \mathrm{H}, \mathrm{d}, J=8.8 \mathrm{~Hz}), 7.42(2 \mathrm{H}, \mathrm{d}, J=8.8 \mathrm{~Hz}), 7.73(2 \mathrm{H}, \mathrm{d}, \\
J=8.8 \mathrm{~Hz}) . \\
{ }^{13} \mathrm{C}-\mathrm{NMR}\left(\mathrm{CDCl}_{3}\right) 55.3,55.4,114.3,114.3,121.3,128.2,128.3,128.4,128.5,128.7,130.2,131.0 \\
159.9,159.9,160.3 .\end{array}$ \\
\hline 17 & $\begin{array}{l}170 \sim 172(\mathrm{dec}) \\
316\left(\mathrm{M}^{+}\right) \\
2115\end{array}$ & $\begin{array}{l}{ }^{1} \mathrm{H}-\mathrm{NMR}\left(\mathrm{CDCl}_{3}\right) 3.87(3 \mathrm{H}, \mathrm{s}), 3.88(3 \mathrm{H}, \mathrm{s}), 6.98(2 \mathrm{H}, \mathrm{d}, J=8.8 \mathrm{~Hz}), 6.99(2 \mathrm{H}, \mathrm{d}, J=8.8 \mathrm{~Hz}), 7.04 \\
(1 \mathrm{H}, \mathrm{s}), 7.48(1 \mathrm{H}, \mathrm{s}), 7.79(2 \mathrm{H}, \mathrm{d}, J=8.8 \mathrm{~Hz}), 7.88(2 \mathrm{H}, \mathrm{d}, J=8.8 \mathrm{~Hz}) . \\
{ }^{13} \mathrm{C}-\mathrm{NMR}\left(\mathrm{CDCl}_{3}\right) 55.4,55.5,103.5,114.6,116.1,117.7,125.0,125.3,129.2,131.7,131.8,161.1, \\
162.0,173.2\end{array}$ \\
\hline 18 & $\begin{array}{l}88 \sim 89 \\
349\left(\mathrm{M}^{+}\right) \\
2111\end{array}$ & $\begin{array}{l}{ }^{1} \mathrm{H}-\mathrm{NMR}\left(\mathrm{CDCl}_{3}\right) 3.84(6 \mathrm{H}, \mathrm{s}), 3.87(3 \mathrm{H}, \mathrm{s}), 6.46(1 \mathrm{H}, \mathrm{s}), 6.90(2 \mathrm{H}, \mathrm{d}, J=8.8 \mathrm{~Hz}), 6.95(2 \mathrm{H}, \mathrm{d}, \\
J=8.8 \mathrm{~Hz}), 7.08(1 \mathrm{H}, \mathrm{s}), 7.30(2 \mathrm{H}, \mathrm{d}, \mathrm{J}=8.8 \mathrm{~Hz}), 7.72(2 \mathrm{H}, \mathrm{d}, J=8.8 \mathrm{~Hz}) . \\
{ }^{13} \mathrm{C}-\mathrm{NMR}\left(\mathrm{CDCl}_{3}\right) 53.1,55.5,55.6,114.4,114.5,125.8,127.1,127.1,128.1,130.3,131.4,131.7 \\
160.5,160.9,168.1,168.6\end{array}$ \\
\hline 19 & $\begin{array}{l}86 \\
235\left(\mathrm{M}^{+}\right) \\
2109\end{array}$ & $\begin{array}{l}{ }^{1} \mathrm{H}-\mathrm{NMR}\left(\mathrm{CDCl}_{3}\right) 3.87(3 \mathrm{H}, \mathrm{s}), 6.94(1 \mathrm{H}, \mathrm{s}), 6.98(2 \mathrm{H}, \mathrm{d}, J=8.8 \mathrm{~Hz}), 7.39(1 \mathrm{H}, \mathrm{t}, J=8.0 \mathrm{~Hz}), 7.44 \\
(2 \mathrm{H}, \mathrm{d}, J=8.0 \mathrm{~Hz}), 7.67(2 \mathrm{H}, \mathrm{d}, J=8.0 \mathrm{~Hz}), 7.80(2 \mathrm{H}, \mathrm{d}, J=8.8 \mathrm{~Hz}) . \\
{ }^{13} \mathrm{C}-\mathrm{NMR}\left(\mathrm{CDCl}_{3}\right) 55.4,114.2,121.2,125.0,125.9,126.6,128.8,128.9,131.2,133.7,160.4 \\
169.5 .\end{array}$ \\
\hline 20 & $\begin{array}{l}91 \\
265\left(\mathrm{M}^{+}\right) \\
2109\end{array}$ & $\begin{array}{l}{ }^{1} \mathrm{H}-\mathrm{NMR}\left(\mathrm{CDCl}_{3}\right) 3.86(3 \mathrm{H}, \mathrm{s}), 3.86(3 \mathrm{H}, \mathrm{s}), 6.82(1 \mathrm{H}, \mathrm{s}), 6.95(2 \mathrm{H}, \mathrm{d}, J=8.8 \mathrm{~Hz}), 6.97(2 \mathrm{H}, \mathrm{d}, \\
J=8.8 \mathrm{~Hz}), 7.59(2 \mathrm{H}, \mathrm{d}, J=8.8 \mathrm{~Hz}), 7.76(2 \mathrm{H}, \mathrm{d}, J=8.8 \mathrm{~Hz}) . \\
{ }^{13} \mathrm{C}-\mathrm{NMR}\left(\mathrm{CDCl}_{3}\right) 55.4,55.4,114.2,114.2,121.0,124.8,126.2,126.3,126.4,130.9,160.1,160.3, \\
{ }^{169.1} .\end{array}$ \\
\hline 24 & $\begin{array}{l}62 \\
210\left(\mathrm{M}^{+}\right) \\
2129\end{array}$ & $\begin{array}{l}{ }^{1} \mathrm{H}-\mathrm{NMR}\left(\mathrm{CDCl}_{3}\right) 3.87(3 \mathrm{H}, \mathrm{s}), 7.02(2 \mathrm{H}, \mathrm{d}, J=8.8 \mathrm{~Hz}), 7.33(1 \mathrm{H}, \mathrm{ddd}, J=2.4,6.8,7.2 \mathrm{~Hz}) 7.42(2 \mathrm{H}, \\
\mathrm{m}), 7.46(2 \mathrm{H}, \mathrm{d}, J=8.8 \mathrm{~Hz}), 7.47(1 \mathrm{H}, \mathrm{m}) . \\
{ }^{13} \mathrm{C}-\mathrm{NMR}\left(\mathrm{CDCl}_{3}\right) 55.3,114.0,124.3,127.6,127.8,129.3,130.2,130.4,138.5,159.7,166.3 .\end{array}$ \\
\hline 28 & $\begin{array}{l}113 \\
316(\mathrm{M}+\mathrm{H})^{+} \\
2121\end{array}$ & $\begin{array}{l}{ }^{1} \mathrm{H}-\mathrm{NMR}\left(\mathrm{CDCl}_{3}\right) 3.87(3 \mathrm{H}, \mathrm{s}), 3.88(3 \mathrm{H}, \mathrm{s}), 7.01(2 \mathrm{H}, \mathrm{d}, J=8.8 \mathrm{~Hz}), 7.03(2 \mathrm{H}, \mathrm{d}, J=8.8 \mathrm{~Hz}), 7.44 \\
(1 \mathrm{H}, \mathrm{d}, J=8.0 \mathrm{~Hz}), 7.49(2 \mathrm{H}, \mathrm{d}, J=8.8 \mathrm{~Hz}), 7.54(2 \mathrm{H}, \mathrm{d}, J=8.8 \mathrm{~Hz}), 7.61(1 \mathrm{H}, \mathrm{dd}, J=2.0,8.0 \mathrm{~Hz}), \\
7.64(1 \mathrm{H}, \mathrm{d}, J=2.0 \mathrm{~Hz}) . \\
{ }^{13} \mathrm{C}-\mathrm{NMR}\left(\mathrm{CDCl}_{3}\right) 55.3,55.4,114.0,114.5,125.8,127.6,128.0,129.0,130.2,130.8,131.1,136.4, \\
137.4,140.5,159.7,159.8,166.2 .\end{array}$ \\
\hline
\end{tabular}


<smiles>[R]c1ccc(C=O)cc1</smiles>

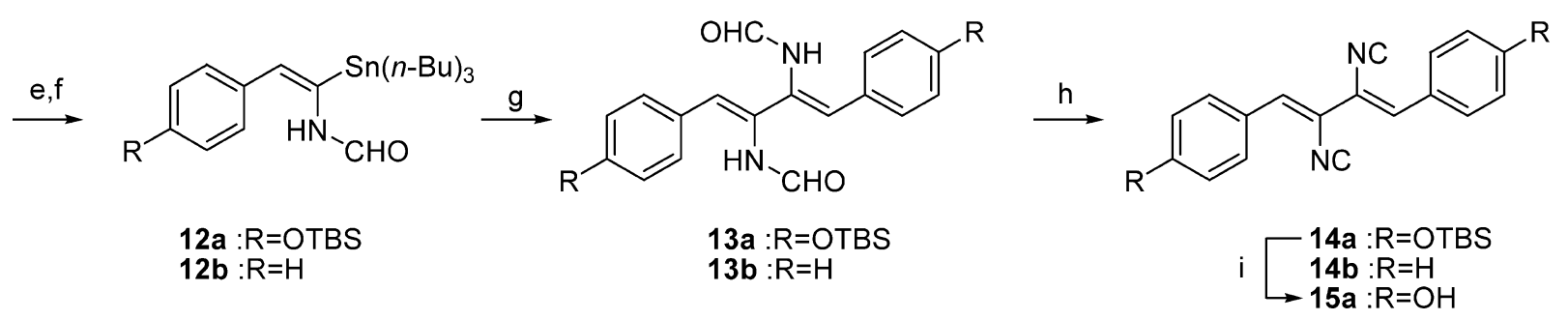

\section{Scheme 2.}

Conditions: a) $\mathrm{PPh}_{3}, \mathrm{CBr}_{4}, \mathrm{Et}_{3} \mathrm{~N}, \mathrm{CH}_{2} \mathrm{Cl}_{2}, 0^{\circ} \mathrm{C}, 1$ hour; b) $n$-BuLi (2 eq), $\mathrm{THF},-78^{\circ} \mathrm{C}$ to $0^{\circ} \mathrm{C}$, 1 hour, then dry ice, $-78^{\circ} \mathrm{C}$ to $0^{\circ} \mathrm{C}, 10$ minutes, 9a: $81 \%$, 9b: $58 \%$ in 2 steps respectively; c) $\mathrm{ClCO}_{2} \mathrm{Et}_{1} \mathrm{Et}_{3} \mathrm{~N}, \mathrm{THF}, 0^{\circ} \mathrm{C}, 30$ minutes then aq. $\mathrm{NH}_{3}, 0^{\circ} \mathrm{C}, 5$ minutes, $\mathbf{1 0 a}: 76 \%, \mathbf{1 0 b}$ :

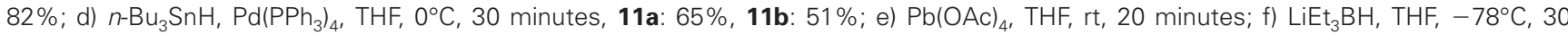
minutes, 12a: $86 \%, \mathbf{1 2 b}$ : $83 \%$ in 2 steps respectively; g) $\mathrm{CuCl}, \mathrm{O}_{2}, \mathrm{THF}, 0^{\circ} \mathrm{C}, 4$ hours, 13a: $50 \%, \mathbf{1 3 b}: 37 \%$; h) triphosgene, $\mathrm{Et}_{3} \mathrm{~N}, \mathrm{CH}_{2} \mathrm{Cl}_{2}$, $0^{\circ} \mathrm{C}, 1$ hour, 14a: $72 \%, \mathbf{1 4 b}: 50 \%$; i) $\mathrm{TBAF}, \mathrm{AcOH}, \mathrm{THF}, 0^{\circ} \mathrm{C}$ to rt, 3 hours, 15a: $85 \%$.<smiles>[R]/C(=C\c1ccc(OC)cc1)C([N])=Cc1ccc(OC)cc1</smiles>

16: $\mathrm{R}=\mathrm{H}(45 \%$ in 2steps)

17: $\mathrm{R}=\mathrm{CN}(48 \%$ in 2 steps)

18: $\mathrm{R}=\mathrm{CO}_{2} \mathrm{Me}(32 \%$ in 2 steps $)$

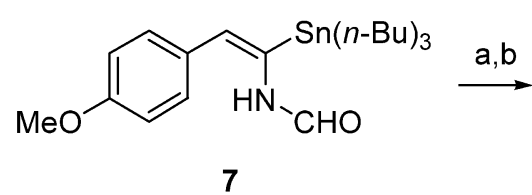

7<smiles>[X]c1ccc(/C(=C/c2ccc(OC)cc2)[N+]#[C-])cc1</smiles>

19: $\mathrm{R}=\mathrm{H}(39 \%$ in 2 steps $)$

20: $R=$ OMe $(40 \%$ in 2 steps $)$

\section{Scheme 3.}

Conditions: a) $\mathrm{ArX}, \mathrm{PdCl}_{2}\left(\mathrm{PPh}_{3}\right)_{2}, \mathrm{Cul}, \mathrm{DMF}$; b) triphosgene, $\mathrm{Et}_{3} \mathrm{~N}, \mathrm{CH}_{2} \mathrm{Cl}_{2}$.

the bioactive compounds, we first modified the substitution on the benzene rings. Xanthocillin X (15a), isolated from Penicillium sp. as an antibiotic in 1950 [8], and a deoxy analog 14b were synthesized from protected 4hydroxybenzaldehyde and benzaldehyde respectively as previously reported (Scheme 2) [7]. The benzaldehydes 8a-b were converted to propiolic acids 9a-b through the dibromoolefins. The mixed anhydrides of $\mathbf{9 a - b}$ were treated with ammonia to give amides $10 \mathbf{a}-\mathbf{b}$, which afforded the (E)-vinylstannanes 11a-b. Successive oxidative rearrangement with $\mathrm{Pb}(\mathrm{OAc})_{4}$ proceeded to the isocyanates which were reduced with $\mathrm{LiEt}_{3} \mathrm{BH}$ to the $\mathrm{N}$ formyl-enamides 12a-b. They were converted to the $(Z, Z)$ dienes 13a-b by homocoupling with $\mathrm{CuCl}$ under oxygen atmosphere, which were dehydrated with triphosgene to the $(Z, Z)$-diisonitrile 14a-b. Finally, removal of TBS groups with TBAF and acetic acid converted 14a to xanthocillin X (15a).

Mono-isonitrile compounds $\mathbf{1 6} \sim \mathbf{2 0}$ were obtained through Stille coupling of the key intermediate 7 [7] and various aryl halides, followed by dehydration (Scheme 3). The biphenyl compound $\mathbf{2 4}$ and the terphenyl compound $\mathbf{2 8}$ were prepared via the substituted $N$-formanilide $\mathbf{2 3}$ and $\mathbf{2 7}$, which were obtained through Suzuki-Miyaura coupling with $p$-methoxyboronic acid (Scheme 4).

The activities of compounds $14 \mathbf{b} \sim 20,24,28$ and 29 in cell proliferation of UT-7/EPO-mpl were evaluated (Fig. 2 4) [9]. The synthetic XDE (2) displayed the same potency as the natural 2, although the $(E, E)$-isomer 29, stereoselectively synthesized as previously reported [7], was inactive (Fig. 2). Unexpectedly, xanthocillin X (15a, with OH groups) had no agonistic potency, while xanthocillin X monomethylether (1) had been reported to be an active compound as well as XDE (2) [6]. The deoxy 
<smiles>COc1ccc(-c2ccccc2N)c(-n2cccc2C)c1</smiles><smiles>CCCCNc1cc(-c2ccc(OC)cc2)ccc1-c1ccc(OC)cc1</smiles>

Scheme 4.

Conditions: a) p-Methoxyphenylboronic acid, $\mathrm{Pd}\left(\mathrm{PPh}_{3}\right)_{4}, \mathrm{Na}_{2} \mathrm{CO}_{3}, \mathrm{DMF}-\mathrm{H}_{2} \mathrm{O}, 60^{\circ} \mathrm{C}, 17$ hours, quant. b) acetic formic anhydride, $\mathrm{CH}_{2} \mathrm{Cl}_{2}$, rt, 1 hour, $68 \%$; c) triphosgene, $\mathrm{Et}_{3} \mathrm{~N}, \mathrm{CH}_{2} \mathrm{Cl}_{2}, 0^{\circ} \mathrm{C}, 30$ minutes, 99\%. d) p-Methoxyphenylboronic acid, $\mathrm{Pd}\left(\mathrm{PPh}_{3}\right)_{4}, \mathrm{TBAC}, \mathrm{KOH}, \mathrm{THF}, 60^{\circ} \mathrm{C}, 3$ hours, $77 \%$; e) $\mathrm{NaBH}_{4}, \mathrm{NiCl}_{2} \cdot 6 \mathrm{H}_{2} \mathrm{O}, \mathrm{MeOH}, 0^{\circ} \mathrm{C}$ to rt, 1 hour, $56 \%$; f) acetic formic anhydride, $\mathrm{CH}_{2} \mathrm{Cl}_{2}, \mathrm{rt}, 30$ minutes, $69 \%$; g) Burgess reagent, $\mathrm{THF}, \mathrm{rt}, 30$ minutes, $93 \%$.

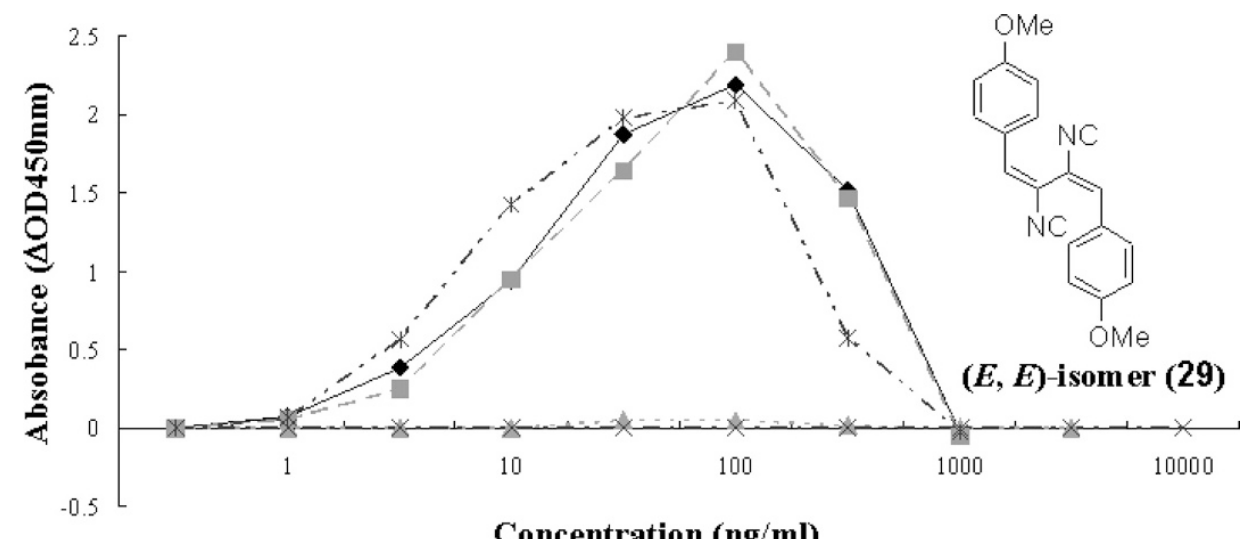

Fig. 2 UT-7/EPO-mpl cell proliferation.

$\bullet, X D E$ (natural); $\mathbf{\square}, X D E$ (synthetic); $\mathbf{\Lambda},(E, E)$-isomer (29); $\times$, Xanthocillin X (15a); $*, \mathbf{1 4 b}$.

analog 14b was as potency as XDE (2). These results suggested that the configuration of $(Z, Z)$-diene is essential for activity and that hydrophilic substituents on the benzene rings augment the biological activity.

Removing one of isonitrile groups did not destroy activity but reduce efficacy (compound 16, Fig. 2). Replacement of an isonitrile with a nitrile group maintained efficacy (compound 17), but the methylester 18 was inactive. These results indicated that two isonitrile groups are not essential; a bulky substituent, even a methylester group, however, has a deleterious effect. 1,2Diphenylethene derivatives $\mathbf{1 9}$ and $\mathbf{2 0}$ were active, but the efficacies were lower in comparison with 2 (Fig. 3). In contrast to the 1,4-diene derivatives, both compounds were light-stable. The biphenyl derivative $\mathbf{2 4}$ was inactive, while the terphenyl compound $\mathbf{2 8}$, which is also light-stable, exhibited efficacy comparable to 2 . Considering the length of the molecules, $\mathbf{2 4}$ is too compact to be active, and moderate size is essential for activity.

In conclusion, these studies demonstrated that 1) the olefin geometry affects the activity, 2) the activity benefits by hydrophobic substituents on benzene rings, 3) two isonitrile groups are not needed to sustain biological activity, and 4) the moderate size of molecule seems to be important. We found the deoxy analog $\mathbf{1 4 b}$ to show equivalent activity, and stable compounds, $\mathbf{2 0}$ and $\mathbf{2 8}$, to 


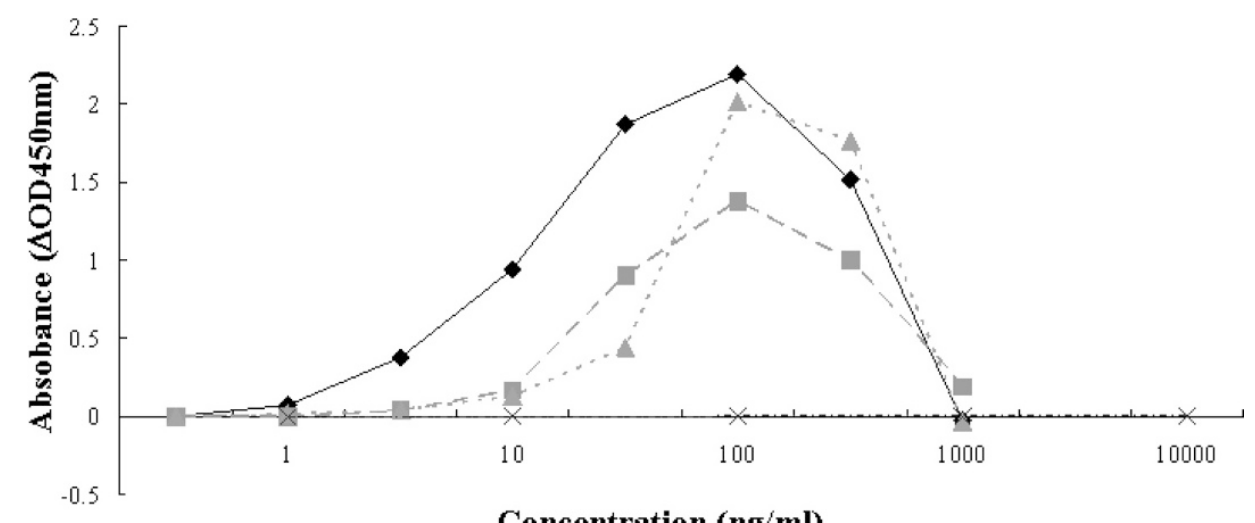

Concentration (ng/ml)

Fig. 3 UT-7/EPO-mpl cell proliferation

$\bullet, \mathrm{XDE}$ (natural); $\mathbf{\square}, \mathbf{1 6} \boldsymbol{\Delta}, \mathbf{1 7} ; \times, 18$.

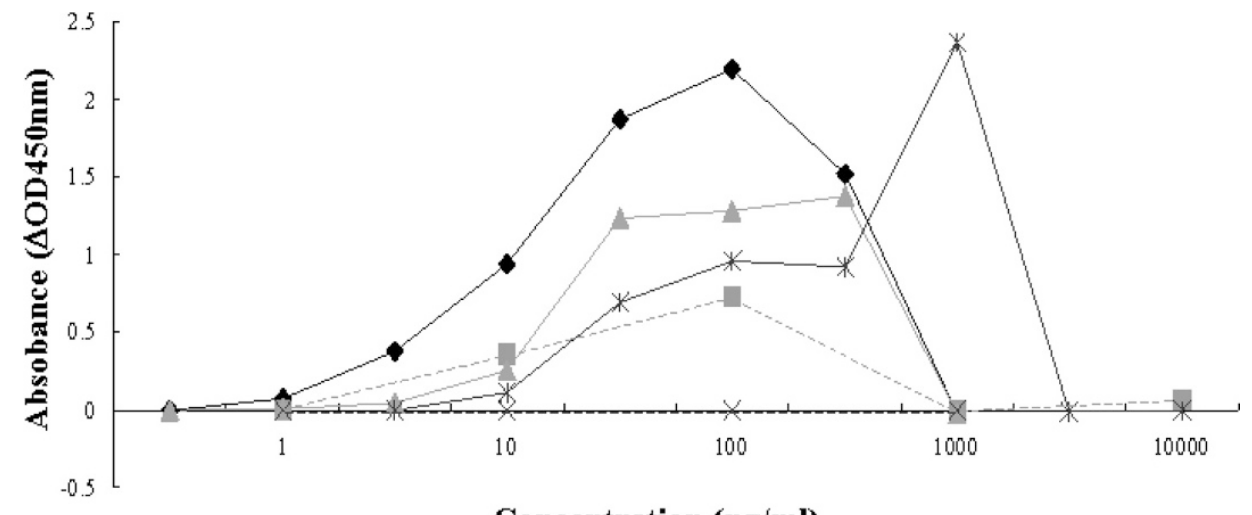

Concentration (ng/ml)

Fig. 4 UT-7/EPO-mpl cell proliferation

$\bullet, \mathrm{XDE}$ (natural); $\mathbf{\square}, \mathbf{1 9} ; \Delta, \mathbf{2 0} \times, \mathbf{2 4} * \mathbf{2 8}$.

maintain the activity. Regardless of the variety of substituents, all active compounds showed inhibition of cell proliferation at high concentration. This effect may be due to the inherent cytotoxicity of the vinyl isonitrile group which unfortunately appears to be indispensable for the activity.

Acknowledgment The authors are grateful for financial support to $21 \mathrm{COE}$ 'Center for Practical Nano-Chemistry', Consolidated Research Institute for Advanced Science and Medical Care, and Grant-in-Aid for Scientific Research (A), Scientific Research (C) and Scientific Research on Priority Areas 16073220 from The Ministry of Education, Culture, Sports, Science and Technology (MEXT).

\section{References}

1. Kaushansky K, Drachman JG. The molecular and cellular biology of thrombopoietin: the primary regurator of platelet production. Oncogene 21: 3359-3367 (2002)

2. Kuter DJ, Begley CG. Recombinant human thrombopoietin: basic biology and evaluation of clinical studies. Blood 100: 3457-3469 (2002)

3. Li J, Yang C, Xia Y, Bertino A, Glaspy J, Roberts M, Kuter DJ. Thrombocytopenia caused by the development of antibodies to thrombopoietin. Blood 98: 3241-3248 (2001)

4. (a) Kimura T, Kaburaki H, Tsujino T, Ikeda Y, Kato H, Watanabe Y. A non-peptide compound which can mimic the effect of thrombopoietin via c-Mpl. FEBS Lett 428: 250-254 (1998)

(b) Duffy KJ, Price AT, Delorme E, Dillon SB, Duquenne C, 
Erickson-Miller C, Giampa L, Huang Y, Keenan RM, Lamb P, Liu N, Miller SG, Rosen J, Shaw AN, Smith H, Wiggall KJ, Zhang L, Luengo JI. Identificaton of a pharmacophore for thrombopoietic activity of small, non-peptidyl molecules. 2. Rational design of naphtho[1,2- $d$ ]imidazole thrombopoietin mimics. J Med Chem 45: 3576-3578 (2002) (c) Nakamura T, Miyakawa Y, Miyamura A, Yamane A, Suzuki H, Ito M, Ohnishi Y, Ishiwata N, Ikeda Y, Tsuruzoe N. A novel nonpeptidyl human c-Mpl activator stimulates human megakaryopoiesis and thrombopoiesis. Blood 107: 4300-4307 (2006)

5. (a) Takatsuki A, Suzuki S, Ando K, Tamura G, Arima K. New antiviral antibiotics; Xanthocillin $\mathrm{X}$ mono- and dimethylether, and methoxyxanthocillin X dimethylether. I. J Antibiot 21: 671-675 (1968)

(b) Takatsuki A, Tamura G, Arima K. New antiviral antibiotics; xanthocillin X mono- and dimethylether, and methoxyxanthocillin $\mathrm{X}$ dimethylether. II. J Antibiot 21: 676-680 (1968)

6. Sakai R, Nakamura T, Nishino T, Yamamoto M, Miyamura A, Miyamoto $\mathrm{H}$, Ishiwata $\mathrm{N}$, Komatsu N, Kamiya $\mathrm{H}$, Tsuruzoe N. Xanthocillin as thrombopoietin mimetic small molecules. Bioorg Med Chem 13: 6388-6395 (2005)

7. Tatsuta K, Yamaguchi T. The first stereoselective total synthesis of antiviral antibiotic, xanthocillin X dimethylether and its stereoisomer. Tetrahedron Lett 46: 5017-5020 (2005)

8. (a) Rothe W. Vorläufige Mitteilung über eine neues Antibiotikum. Die Pharmazie 5: 190 (1950)

(b) Beiersdorf R, Ahrens W. Untersuchungene über die antibakteriellen und pharmakodynamischen Eigenschaften das neuen Antibioticums Xanthocillin. Die Pharmazie 8: 796-801 (1953)

(c) Hagedron I, Tonjes H. Konstitutionsaufklärung von Xanthocillin - einem neuen Antibioticum. Die Pharmazie
12: $567-580$ (1957)

9. UT-7/EPO-mpl (kindly donated by Dr Norio Komatsu, University of Yamanashi) was prepared by introducing a vector that induces expression of human TPO receptor gene (c-mpl) into human leukemia cell line UT-7/EPO [10]. Proliferation of UT-7/EPO-mpl is stimulated by TPO, while its parental cell line UT7/EPO exhibits no response to TPO. The activities of the compounds on the cell proliferation of UT-7/EPO-mpl cell were evaluated according to the reported procedure [5]. Briefly, the cells were subcultured in Iscove's modified Dulbecco's medium (IMDM; Gibco) containing $10 \%$ fetal bovine serum (FBS; BioWest) using a $\mathrm{CO}_{2}$ incubator $\left(5 \% \mathrm{CO}_{2}, 37^{\circ} \mathrm{C}\right)$. The subcultured cells were washed twice with phosphate buffered saline (PBS) and suspended in IMDM containing $10 \%$ FBS at a cell density of $6 \times 10^{4}$ cells $/ \mathrm{ml}$. The cell suspension was transferred to a 96-well tissue culture plate in $100-\mu 1$ aliquots. Then either TPO (PeproTech EC) or the compound dissolved in DMSO was diluted 83 -fold with IMDM containing $10 \%$ FBS and added to the aforementioned cell suspension in $20-\mu 1$ aliquots. The suspension was incubated in a $\mathrm{CO}_{2}$ incubator $\left(5 \% \mathrm{CO}_{2}, 37^{\circ} \mathrm{C}\right)$ for 4 days. Cell proliferation was assayed using WST-8 reagent (Kishida Chemical) according to instructions by the manufacturer. A $10-\mu 1$ aliquot of $5 \mathrm{mM}$ WST- 8 reagent was added to each well of the tissue culture plate, and the plate was incubated at $37^{\circ} \mathrm{C}$ for 4 hours. The formazan pigment generated was detected by measuring the absorbance at $450 \mathrm{~nm}$ with a 96-well microplate reader (Nihon Molecular Devices, Spectramax 190)

10. Takatoku M, Kametaka M, Shimizu R, Miura Y, Komatsu N. Identification of functional domains of the human thrombopoietin receptor required for growth and differentiation of megakaryocytic cells. J Biol Chem 272: 7259-7263 (1997). 